\title{
Efektivitas Penggunaan Jari Tangan dalam Mengembangkan Motorik Halus Anak di Taman Kanak-kanak Bhayangkari 1 Padang
}

\author{
Finy Putri Utami ${ }^{1}$, Indra Yeni $^{2}$, Rakimahwati ${ }^{3}$ \\ Program Studi PG-PAUD Fakultas IImu Pendidikan \\ Universitas Negeri Padang \\ Email : finyputri.utami@yahoo.com
}

\begin{abstract}
Abstrak
Penelitian ini bertujuan untuk mengetahui efektivitas penggunaan jari tangan dalam mengembangkan motorik halus anak di TK Bhayangkari 1 Padang. Jenis penelitian yang digunakan adalah metode kuantitatif dengan jenis eksperimen atau penelitian quasi experiment (eksperimen semu) dengan menggunakan jari tangan. Hasil penelitian ini diperoleh nilai rata-rata nilai yang diperoleh dari kelas eksperimen yang menggunakan jari tangan lebih tinggi $(83,33)$ dibandingkan kelas kontrol yang menggunakan pembelajaran konvensional $(73,77)$. Berdasarkan perhitungan $t$-test diperoleh bahwa $t_{\text {hitung }}$ lebih besar dari $t_{\text {tabel }}$ menunjukkan bahwa terdapat pengaruh yang signifikan terhadap kemampuan motorik halus anak. Dengan demikian disimpulkan bahwa dengan menggunakan jari tangan sangat efektif dalam mengembangkan motorik halus anak di TK Bhayangkari 1 Padang.
\end{abstract}

Kata Kunci : Penggunaan Jari Tangan, kemampuan motorik halus

\section{PENDAHULUAN}

Perkembangan anak usia dini merupakan masa-masa yang sangat menentukan bagi anak untuk menjalani kehidupan dimasa akan datang. Perkembangan anak pada masa tersebut memberikan dampak terhadap kemampuan intelektual, karakter, dan kemampuan bersosialisasi dengan lingkungan. Dalam undang-undang Nomor 20 Tahun 2003 pasal 1 angka 14 menyatakan bahwa Pendidikan Anak Usia Dini (PAUD) adalah suatu upaya pembinaan yang ditujukan kepada anak sejak lahir sampai dengan usia enam tahun yang dilakukan melalui pemberian rangsangan pendidikan untuk membantu pertumbuhan dan perkembangan jasmani dan rohani agar anak memiliki kesiapan dalam memasuki pendidikan lebih lanjut.

Perkembangan pada anak saling berkaitan, dengan kondisi badan yang sehat, memiliki cukup gizi dan dididik secara baik dan benar. Proses perkembangan anak diantaranya proses perkembangan biologis, porses 
perkembangan kognitif, dan proses perkembangan psikososial. Proses perkembangan biologis mencangkup perubahan-perubahan yang terjadi pada tubuh, seperti pertumbuhan otak, otot, sistem saraf, struktur tulang dan organ-organ lain serta cara menggunakan tubuh (keterampilan motorik). Misalnya menggunakan kaki untuk berdiri, berjalan, berlari, menendang dan keterampilan lainnya. Proses perkembangan kognitif berpengaruh pada kemampuan berpikir dan kemahiran berbahasa. Proses perkembangan ini, berkaitan dengan proses belajar, mengamati(observasi), percobaan(eksperiment), dan menghafal. Perkembangan kognitif anak dan pengalaman belajar sangat erat kaitannya dan saling berpengaruh satu sama lain. Misalnya, anak yang kurang bisa dan pemalu untuk menceritakan kembali sebuah dongeng, setelah bersekolah, anak bisa dan mau untuk menceritakannya di depan kelas. Proses perkembangan psikososial berhubungan dengan perubahan dalam psikis seperti perasaan, emosi, serta perkembangan hubungan dengan orang lain, seperti dengan keluarga, guru, teman. Misalnya seperti perkembangan hubungan pertemanan antara anak.

Pendidikan dapat tercapai, dengan memerhatikan pertumbuhan dan perkembangan anak dimulai sedini mungkin agar segala kemampuan dan aspek perkembangan yang ada pada anak dapat berkembang dengan optimal. Dalam hal ini peran pendidik dalam mengoptimalkan kemampuan anak menjadi sangat penting, maka perlu pemberian rangsangan dan memfasilitasi perkembangannya. Semakin banyak rangsangan terhadap diri anak semakin terbuka peluang untuk anak menjadi orang yang sukses.

Taman Kanak-kanak merupakan salah satu wadah yang digunakan untuk mempersiapkan pertumbuhan dan perkembangan anak. Adapun tujuan pendidikan Taman Kanak-kanak adalah: (1) untuk membantu pertumbuhan jasmani dan rohani anak, (2) mempersiapkan anak untuk pendidikan lebih lanjut, dan (3) mengembangkan kepribadian dan potensi diri anak.

Berbagai macam aspek yang dikembangkan pada diri anak di Taman Kanak-kanak. Salah satu diantaranya adalah kemampuan motorik anak. Perkembangan motorik merupakan proses tumbuh kembang kemampuan gerak seorang anak. Pada dasarnya, perkembangan ini berkembang sejalan dengan kematangan saraf dan otot. Perkembangan motorik terbagi menjadi dua kelompok, yaitu motorik kasar dan motorik halus. Motorik kasar adalah gerak tubuh yang menggunakan otot-otot besar atau sebagian besar atau seluruh anggota tubuh, seperti berjalan, melompat, melempar, berlari, atau mengayuh sepeda roda tiga. Sedangkan motorik halus adalah gerak tubuh yang menggunakan jari jemari dan tangan, serta melatih koordinasi mata seperti menulis, melipat, menggunting, meronce, dan lain sebagainya. 
Kemampuan motorik halus anak sangat penting untuk dikembangkan karena secara tidak langsung perkembangan motorik halus anak akan menentukan keterampilan dalam bergerak misalnya; menyikat gigi, mengancingkan baju, menyisir rambut, memakai sepatu sendiri. Selain itu dengan perkembangan motorik halus anak yang optimal di usia ini, dapat menjadi kesukaan tersendiri bagi anak, misalkan dalam hal kegiatan mewarnai atau menggambar, dengan kegemaran dan hobinya dapat mewujudkan keinginan untuk menjadi pelukis dewasanya.

Di Taman Kanak-kanak, bermain sambil belajar merupakan dasar dalam kegiatan pembelajaran. Untuk mengembangkan motorik halus anak harus dilakukan melalui kegiatan yang menarik, bervariasi dan menyenangkan bagi anak yaitu dengan bermain, karena bermain merupakan aktivitas yang disenangi anak. Melalui bermain dapat memberikan pengetahuan pada anak dan mengembangkan berbagai aspek perkembangan.

Salah satu bentuk yang dapat mengembangkan aspek perkembangan anak yaitu dengan penggunaan jari tangan sebagai media. Kegiatan ini, merupakan salah satu aktivitas yang dapat mengembangkan kemampuan motorik halus anak. Penggunaan jari tangan adalah suatu kegiatan bermain dalam membuat binatang dengan menggunakan jiplakan jari tangan. Misalnya membuat binatang kupu-kupu atau burung. Jiplakan jari tangan yang akannn dijadikan sayap kupu-kupu atau burung. Melalui kegiatan ini dapat mengembangkan kemampuan motorik halus anak seperti menjiplak jari tangan, menggunting, mewarnai dan menempel.

Berdasarkan pengamatan peneliti pada saat observasi di Taman Kanak-kanak (TK) Bhayangkari 1 Padang bahwa kemampuan motorik halus anak belum berkembang sesuai dengan tingkat pencapaian perkembangan. Ini terlihat saat melakukan kegiatan pengembangan motorik halus, masih adanya anak yang belum bisa memegang pensil dengan benar, belum bisa menggunting dengan rapi, belum bisa menempel dengan teratur, dan belum bisa melipat dengan benar dan rapi. Kegiatan yang sering diberikan guru dalam mengembangkan motorik halus anak seperti mewarnai, menebalkan huruf, dan menggambar bebas dengan menggunakan kertas koran, kertas lipat. Pada saat kegiatan berlangsung, masih terlihat guru yang kurang memperhatikan kegiatan yang dilakukan anak secara keseluruhan hal ini terjadi karena jumlah anak yang terlalu banyak sehingga guru kurang mengetahui sampai dimanakah perkembangan motorik halus setiap anak. Kurangnya alat atau media dalam kegiatan mengembangkan motorik halus anak. Selain itu guru masih kurang memvariasikan kreatif dalam menciptakan sesuatu yang baru dalam mengembangkan kemampuan motorik halus pada anak. 
Menurut Mulyani dan Juliska (2007: 2) gerak motorik halus adalah gerak yang hanya melibatkan bagian tubuh tertentu hanya menggunakan otot-otot kecil, dan tidak membutuhkan tenaga yang terlalu besar, namun membutuhkan koordinasi mata dengan anggota tubuh yang bergerak. Contohnya, gerakan jari dan pergelangan tangan. Sedangkan menurut Hidayati (2010: 62) juga mengemukakan mengenai perkembangan motorik halus adalah perkembangan gerakan yang dilakukan anak dengan sebagian anggota tubuh tertentu atau menggunakan otot-otot kecil, seperti menulis, menggunting, dan menyusun balok.

Media merupakan salah satu alat penyampai materi kepada peserta didik. Media tidak hanya dipahami sebagai alat peraga, tetapi juga sebagai pembawa informasi atau pesan kepada peserta didik. Menurut Education Association (NEA) dalam Fadlillah (2012: 206) mengartikan media sebagai benda yang dapat dimanipulasi, dilihat, didengar, dibaca atau dibicarakan beserta instrument yang dipergunakan, baik dalam kegiatan belajar mengajar yang dapat mempengaruhi efektivitas program instruksional. Sedangkan menurut Latif (2013:152) media adalah segala sesuatu yang dapat dijadikan bahan (software) dan alat (hardware) untuk bermain yang membuat AUD mampu memperoleh pengetahuan, keterampilan, dan menentukan sikap.

Menurut Sudono (2006: 1) bermain adalah suatu kegiatan yang dilakukan oleh anak dengan atau tanpa mempergunakan alat yang dapat menghasilkan pengertian atau memberikan informasi, serta memberi kesenangan maupun mengembangkan imajinasi pada anak. Sejalan dengan pendapat Desmita (2009: 141) permainan bagi anak-anak adalah suatu kegiatan yang menyenangkan, dilakukan hanya untuk aktivitas sendiri, bukan karena ingin memperoleh sesuatu dari aktivitas yang dilakukan. Bagi anak proses melakukan sesuatu dalam bermain lebih menarik dan menyenangkan dibandingkan dengan hasil yang didapatkannya.

Dalam Kamus Besar Bahasa Indonesia (KBBI) (2008: 194) jari tangan adalah anggota badan dari siku sampai ke ujung jari atau dari pergelangan sampai ujung jari tangan atau kaki yang beruas-ruas dengan berjumlah lima. Sedangkan dalam Wikipedia Bahasa Indonesia, Ensiklopedia Bebas yang diunggah pada 31 Oktober 2015 menjelaskan, jari tangan merupakan suatu bagian tubuh yang berada pada tangan dan kaki baik kiri maupun kanan. Pada manusia normal jari berjumlah lima, yaitu:1. Jempol atau ibu jari; 2. Jari telunjuk; 3. Jari tengah merupakan jari yang paling panjang diantara jari tangan; 4. Jari manis; 5. Jari kelingking.

\section{METODE PENELITIAN}

Berdasarkan penelitian yang dilakukan yaitu "efektivitas penggunaan jari tangan dalam mengembangkan motorik halus anak di 
Taman Kanak-kanak Bhayangkari 1 Padang", maka pendekatan penelitian ini adalah metode penelitian kuantitatif, dengan jenis penelitian quasy exsperimental. Menurut Sugiyono (2012: 116) desain quasy experimental mempunyai kelompok kontrol, tetapi tidak dapat berfungsi sepenuhnya untuk mengontrol variabel-variabel luar yang mempengaruhi pelaksanaan eksperimen.

Populasi dalam penelitian ini adalah murid Taman Kanak-kanak Bhayangkari 1 Padang yang beralamat yang beralamat di jalan Rasuna Said No.78, Kelurahan Alai Parak Kopi, Kecamatan Padang Utara, Kota Padang. Taman Kanak-kanak Bhayangkari 1 Padang ini berada dibawah pimpinan ibu Rolania,S.E dan diasuh oleh 7 orang tenaga pendidik.

Adapun teknik pengambilan sampel yang dilakukan dalam penelitian ini adalah teknik cluster sampling, yaitu teknik penentuan sampel apabila populasi cukup besar, sehingga perlu dibuat beberapa kelas atau kelompok.

Berdasarkan konsep di atas, maka kelompok yang akan diambil dalam penelitian ini adalah kelompok B4 dan kelompok B5.Dimana kelompok B5 dijadikan kelas eksperimen dan kelas B4 dijadikan kelas kontrol dengan perimbangan jumlah anak kedua kelompok sama yaitu masing-masing 18 orang, usia anak yang sama, tingkat kemampuan anak yang sama, fasilitas belajar yang sama, dan rekomendasi dari guru kedua kelompok dan kepala sekolah TK Bhayangkari 1 Padang.

Instrumen penelitian yang digunakan dalam penelitian ini adalah tes. Tes dikatakan valid apabila tes itu dapat mengukur apa yang hendak diukur. Instrument ini menggunakan skala likert untuk penilaiannya.Dengan kriteria penilaian yaitu Sangat Baik diberi skor 5 (SB), Baik diberi skor 4 (B), cukup baik diberi skor 3 (CB), Tidak Baik diberi skor 2 (TB), Sangat Tidak Baik diberi skor 1 (STB).

Tes yang peneliti gunakan berupa tes perbuatan. Tes perbuatan adalah tes yang menuntut jawaban dari peserta didik dalam bentuk perilaku, tindakan atau perbuatan.Jadi anak berbuat sesuai dengan perintah atau pertanyaan yang diberikan guru.

Menurut Arikunto (2010: 211) validitas adalah suatu ukuran yang menunjukkan tingkat-tingkat kevalidan atau kesalihan sesuatu instrumen. Suatu instrumen yang valid atau sahih mempuyai validitas tinggi. Sebaliknya, instrumen yang kurang valid berarti memiliki validitas rendah. Sebuah instrumen dikatakan valid apabila dapat mengungkap data dari variabel yang diteliti secara tepat. Tinggi rendahnya validitas instrumen menunjukkan sejauh mana data yang terkumpul tidak menyimpang dari gambaran tentang validitas yang dimaksud. Reliabilitas tes merupakan 
suatu ukuran ketepatan suatu tes apabila diteskan ke objek yang sama. Untuk menentukan reliabilitas tes dipakai rumus alpha.

Teknik analisis data yang digunakan dalam penelitian ini adalah membandingkan dari dua rata-rata nilai, sehingga dilakukan dengan uji $t$ (t-tes). Namun sebelum itu, terlebih dahulu melakukan uji normalitas dan uji homogenitas. Untuk melakukan analisis perbedaan tersebut, perlu dilakukan uji normalitas. Seperti yang dikatakan Syafril (2010: 211) : Uji normalitas digunakan unuk mengetahui apakah data yang akan diolah berasal dari data berdistribusi normal. Uji normalitas dilakukan sebelum mengolah data dengan teknik korelasi product moment, regresi,t-test, dan anava dan sebagainya. Teknik yang sering digunakan untuk uji normalitas data adalah uji liliefors.

Sebelum data diolah agar diketahui suatu data berdistribusi normal atau tidak maka dilakukan uji liliefors terlebih dahulu.Salah satu teknik yang sering digunakan untuk menguji homogenitas varians populasi adalah dengan menggunakan uji Bartlett.Jika sudah diketahui sebuah data berdistribusi normal dan bersifat homogeny baru dilaukan analisis data sesuai dengan teknik analisis yang telah dilakukan, yaitu mencari perbandingan dengan menggunakan t-tes.Menguji data yang telah diperoleh tersebut dengan rumus t-tes.

\section{HASIL}

Untuk menarik kesimpulan dari hasil penelitian, dilakukan uji hipotesis dengan menggunakan uji t. Sebelum melakukan uji t terlebih dahulu dilakukan uji normalitas dan uji homogenitas terhadap hasil penelitian.

Berdasarkan hasil penelitian anak yaitu dalam mengembangkan motorik halus anak pada kelas eksperimen dan kelas kontrol, diperoleh hasil bahwa kemampuan motorik halus anak di kelas eksperimen (kelompok B5) lebih tinggi dibandingkan pada kelas kontrol (kelompok B4). Berdasarkan uji normalitas kelas eksperimen dan kelas kontrol diperoleh harga $L_{0}$ dan $L_{t}$ pada taraf nyata 0,05 untuk $N=18$ seperti tabel berikut :

Tabel 1.

Hasil Perhitungan Pengujian Liliefors Pre-test Kelas Eksperimen dan Kelas Kontrol

\begin{tabular}{|c|c|c|c|c|c|c|}
\hline No & Kelas & $\mathbf{N}$ & $\mathbf{A}$ & $\mathbf{L}_{\mathbf{0}}$ & $\mathbf{L}_{\mathbf{t}}$ & keterangan \\
\hline 1 & Eksperimen & 18 & 0,05 & 0,1410 & 0,200 & Normal \\
\hline 2 & Kontrol & 18 & 0,05 & 0,1065 & 0,200 & Normal \\
\hline
\end{tabular}

Berdasarkan tabel 1 terlihat bahwa kelompok eksperimen nilai $L_{\text {hitung }} \mathbf{0 , 1 4 1 0}$ lebih kecil dari $L_{\text {tabel }} \mathbf{0 , 2 0 0}$ untuk $\alpha 0,05$. Dengan demikian 
nilai kelompok eksperimen berasal dari data yang berdistribusi normal. Untuk kelompok kontrol diperoleh $L_{\text {hitung }} \mathbf{0 , 1 0 6 5}$ lebih kecil dari $L_{\text {tabel }} \mathbf{0 , 2 0 0}$ untuk $\alpha 0,05$. Ini berarti bahwa data kelompok kontrol berasal dari data yang berdistribusi normal.

Pengujian persyaratan yang kedua adalah pengujian homogenitas dengan menggunakan uji Barlett. Pengujian ini bertujuan untuk mengetahui apakah data berasal dari kelompok yang homogen, antara kelas eksperimen dan kelas kontrol. Jika chi kuadrat hitung <chi kuadrat tabel berarti data berasal dari kelompok yang homogen.

Hal ini sesuai dengan apa yang dikemukakan oleh Syafril (2010: 208) bahwa :"Jika hasil perhitungan dari $x^{2}$ hitung lebih kecil dari $x^{2}$ tabelberarti bahwa data berasal dari kelompok yang homogen, sebaliknya jikax ${ }^{2}$ hitung lebih besar daripada $\mathrm{x}^{2}$ tabel maka kelompok tersebut tidak homogen ".

Hasil perhitungan diperoleh $x^{2}$ hitung sebesar 0,480 seperti yang di tuliskan dalam tabel berikut :

Tabel 2.

Hasil Perhitungan Uji HomogenitasPre-test Kelas Eksperimen dan Kelas Kontrol

\begin{tabular}{|c|c|c|c|c|}
\hline Kelas & $\mathrm{A}$ & $\mathrm{X}^{2}{ }_{\text {hitung }}$ & $\mathrm{X}^{2}$ table & Kesimpulan \\
\cline { 1 - 4 } Eksperimen & \multirow{2}{*}{0,05} & 0,475 & 3,841 & Homogen \\
\hline
\end{tabular}

Dari Tabel 2 tampak bahwa $\mathrm{x}^{2}$ hitung kelas eksperimen dan kelas kontrol lebih kecil dari $x^{2}$ tabel $\left(x^{2}\right.$ hitung $<x^{2}$ tabel $)$, berarti kelas eksperimen dan kelas kontrol memiliki varians yang homogen.

Setelah dilakukan uji normalitas dan uji homogenitas, diketahui bahwa kedua kelas sampel berdistribusi normal dan mempunyai varians homogen. Maka dapat dilanjutkan dengan pengujian hipotesis dengan menggunakan teknik t-tes.

Jika $\boldsymbol{t}_{\text {hitung }}>\boldsymbol{t}_{\text {tabel }}$ maka $\mathrm{H}_{\mathrm{o}}$ ditolak dan $\mathrm{H}_{\mathrm{a}}$ diterima

Jika $\boldsymbol{t}_{\text {hitung }}<\boldsymbol{t}_{\text {tabe/maka }} \mathrm{H}_{\mathrm{o}}$ diterima dan $\mathrm{H}_{\mathrm{a}}$ ditolak

Berikut ini akan digambarkan pengolahan data dengan t-tes:

Tabel 3.

Hasil Perhitungan Nilai Pre-test

Kelas Eksperimen dan Kelas Kontrol

\begin{tabular}{|c|c|c|}
\hline Aspek & Kelas Eksperimen & Kelas Kontrol \\
\hline $\mathrm{N}$ & 18 & 18 \\
\hline $\bar{X}$ & 69,55 & 66,66 \\
\hline $\mathrm{SD}^{2}$ & 42,90 & 46,10 \\
\hline
\end{tabular}


T tabel untuk taraf nyata $\alpha=0,05(5 \%)$ dengan df sebesar 34 adalah $=2,03224$ Dengan demikian, dapat diketahui bahwa pada taraf nyata

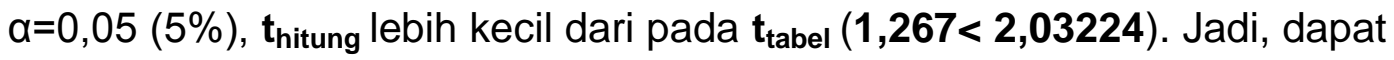
disimpulkan bahwa tidak terdapat perbedaan yang signifikan antara kemampuan dalam mengembangkan motorik halus anak dikelas eksperimen dan kontrol dalam nilai pre-test.

Tabel 4.

Hasil Perhitungan Pre-test Pengujian dengan t-test

\begin{tabular}{|c|l|c|c|c|c|c|}
\hline No & Kelompok & $\mathbf{N}$ & $\begin{array}{c}\text { Hasil } \\
\text { Rata-rata }\end{array}$ & $t_{\text {hitung }}$ & $\begin{array}{c}t_{\text {tabel }} \\
\mathbf{a ~ 0 , 0 5}\end{array}$ & $\begin{array}{c}\text { Keputusa } \\
\mathbf{n}\end{array}$ \\
\hline $\mathbf{1}$ & Eksperimen & 18 & 69,55 & \multirow{2}{*}{1,267} & 2,03224 & Terima $\mathrm{H}_{\mathrm{o}}$ \\
\hline $\mathbf{2}$ & Kontrol & 18 & 66,66 & & & \\
\hline
\end{tabular}

T tabel untuk taraf nyata $\alpha=0,05(5 \%)$ dengan df sebesar 34 adalah $=2,03224$ Dengan demikian, dapat diketahui bahwa pada taraf nyata

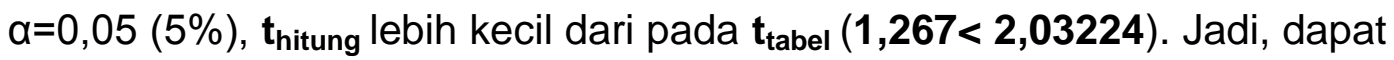
disimpulkan bahwa tidak terdapat efektivitas yang signifikan antara hasil pre-test (kemampuan awal) dalam mengembangkan motorik halus anak di kelas eksperimen dengan kelas kontrol di TK Bhayangkari 1 Padang.

Data post test penelitian kelas eksperimen dan kelas kontrol diolah untuk menentukan uji normalitas. Pada uji normalitas ini digunakan uji Liliefors seperti yang dikemukakan pada teknik analisis data. Analisis normalitas pada kelas eksperimen dan kelas kontrol.

Uji normalitas kelas eksperimen dan kelas kontrol diperoleh harga $L_{0}$ dan $L_{t}$ pada taraf nyata 0,05 untuk $N=18$ seperti pada tabel berikut:

Tabel 5

Hasil Perhitungan Pengujian Liliefors Post-test Kelas Eksperimen dan Kelas Kontrol

\begin{tabular}{|c|l|c|c|c|c|c|}
\hline No & \multicolumn{1}{|c|}{ Kelas } & $\mathbf{N}$ & $\mathbf{A}$ & $\mathbf{L}_{\mathbf{0}}$ & $\mathbf{L}_{\mathbf{t}}$ & Keterangan \\
\hline 1 & $\begin{array}{l}\text { Eksperime } \\
\mathrm{n}\end{array}$ & 18 & 0,05 & 0,1831 & 0,200 & Normal \\
\hline 2 & Kontrol & 18 & 0,05 & 0,1526 & 0,200 & Normal \\
\hline
\end{tabular}

Pada tabel 5 terlihat bahwa kelompok eksperimen nilai $L$ hitung $\mathbf{0 , 1 8 3 1}$ lebih kecil dari $L$ tabel $\mathbf{0 , 2 0 0}$ untuk $\alpha$ 0,05. Dengan demikian nilai kelas eksperimen berasal dari data yang berdistribusi normal. Untuk kelas kontrol diperoleh $L$ hitung $\mathbf{0 , 1 5 2 6}$ lebih kecil dari $L$ tabel $\mathbf{0 , 2 0 0}$ untuk $\alpha$ 0,05 . Ini berarti bahwa data kelas kontrol berasal dari data yang berdistribusi normal.

Pengujian persyaratan yang kedua adalah pengujian homogenitas dengan menggunakan uji Barlett. Pengujian ini bertujuan untuk 
mengetahui apakah data berasal dari kelompok yang homogen, antara kelas eksperimen dan kelas kontrol. Jika chi kuadrat hitung < chi kuadrat tabel berarti data berasal dari kelompok yang homogen.

Hal ini sesuai dengan apa yang dikemukakan oleh Syafril (2010: 208) bahwa :"Jika hasil perhitungan dari $x^{2}$ hitung lebih kecil dari $x^{2}$ tabelberarti bahwa data berasal dari kelompok yang homogen, sebaliknya jikax ${ }^{2}$ hitung lebih besar daripada $\mathrm{x}_{\text {tabel }}^{2}$ maka kelompok tersebut tidak homogen ".

Hasil perhitungan diperoleh $x^{2}$ hitung sebesar 0,375 seperti yang di tuliskan dalam tabel berikut :

Tabel 6.

Hasil Uji Homogenitas Post-test Kelompok Eksperimen dan Kelompok Kontrol

\begin{tabular}{|c|c|c|c|c|}
\hline Kelas & $\mathrm{A}$ & $\mathrm{X}^{2}$ hitung & $\mathrm{X}_{\text {table }}^{2}$ & Kesimpulan \\
\cline { 1 - 5 } Eksperimen & 0,05 & 0,375 & 3,841 & Homogen \\
\cline { 1 - 3 } Kontrol & 0,05 & \\
\hline
\end{tabular}

Dari Tabel 6 tampak bahwa $x^{2}$ hitung kelompok eksperimen dan kelompok kontrol lebih kecil dari $x^{2}$ tabel $\left(x^{2}\right.$ hitung $<x^{2}$ tabel), berarti kelas eksperimen dan kelas kontrol memiliki varians yang homogen.

Setelah dilakukan uji normalitas dan uji homogenitas, diketahui bahwa kedua kelompok sampel berdistribusi normal dan mempunyai varians homogen. Maka dapat dilanjutkan dengan pengujian hipotesis dengan menggunakan teknik t-test.

Jika $\boldsymbol{t}_{\text {hitung }}>\boldsymbol{t}_{\text {tabel }}$ maka $\mathrm{H}_{\mathrm{o}}$ ditolak dan $\mathrm{H}_{\mathrm{a}}$ diterima

Jika $\boldsymbol{t}_{\text {hitung }}<\boldsymbol{t}_{\text {tabermaka }} \mathrm{H}_{0}$ diterima dan $\mathrm{H}_{\mathrm{a}}$ ditolak

Berikut ini akan digambarkan pengolahan data dengan t-test:

Tabel 7.

Hasil Perhitungan Nilai Post-test Kelompok Eksperimen dan Kelompok Kontrol

\begin{tabular}{|c|c|c|}
\hline Aspek & Kelas Eksperimen & Kelas Kontrol \\
\hline $\mathrm{N}$ & 18 & 18 \\
\hline $\bar{X}$ & 83,33 & 73,77 \\
\hline $\mathrm{SD}^{2}$ & 48,30 & 43,03 \\
\hline
\end{tabular}

T tabel untuk taraf nyata $\alpha=0,05(5 \%)$ dengan df sebesar 34 adalah $=2,03224$ Dengan demikian, dapat diketahui bahwa pada taraf nyata $\alpha=0,05(5 \%), t_{\text {hitung }}$ lebih besar dari pada $\mathbf{t}_{\text {tabel }}(\mathbf{4 , 1 3 8}>\mathbf{2 , 0 3 2 2 4})$. Jadi, dapat disimpulkan bahwa $\mathrm{H}_{\mathrm{a}}$ diterima yaitu: terdapat efektivitas yang signifikan dari penggunaan jari tangan dalam mengembangkan motorik halus anak di TK Bhayangkari 1 Padang. 
Tabel 8.

Hasil Perhitungan Post-test Pengujian Dengan t-test

\begin{tabular}{|c|l|c|c|c|c|c|}
\hline No & Kelompok & $\mathbf{N}$ & $\begin{array}{c}\text { Hasil } \\
\text { Rata-rata }\end{array}$ & $\begin{array}{c}\mathbf{t} \\
\text { hitung }\end{array}$ & $\begin{array}{c}\mathbf{t} \text { table } \\
\mathbf{\alpha} \mathbf{0 , 0 5}\end{array}$ & Keputusan \\
\hline $\mathbf{1}$ & Eksperimen & 18 & 83,33 & 4,138 & 2,03224 & Tolak $\mathrm{H}_{0}$ \\
\hline $\mathbf{2}$ & Kontrol & 18 & 73,77 & & \\
\hline
\end{tabular}

Tabel di atas dapat disimpulkan bahwa $\mathrm{H}_{\mathrm{a}}$ diterima yaitu: terdapat efektivitas yang signifikan dari penggunaan jari tangan dalam mengembangkan motorik halus anak di TK Bhayangkari 1 Padang.

Setelah dilakukan perhitungan nilai pre-test dan post-test kelas eksperimen dan kelas kontrol maka selanjutnya akan dilakukan perbandingan antara nilai pre-test dan nilai post-test, yang tujuannya untuk melihat apakah ada perbedaan nilai post-test dan nilai pre-test anak.

Perbandingan hasil perhitungan nilai pre-test dan nilai post-test. Pada pre-test nilai tertinggi yang diperoleh anak kelas eksperimen yaitu 80 dan nilai terendah 60 , dengan rata-rata 69,55 sedangkan pada kelas kontrol nilai tertinggi yang diperoleh anak yaitu 76 dan nilai terendah 56 dengan rata-rata 66,66 . Pada post-test nilai tertinggi yang diperoleh anak kelas eksperimen yaitu 96 dan nilai terendah 76 dengan rata-rata 83,33 sedangkan pada kelas kontrol post-test nilai tertinggi yang diperoleh anak yaitu 84 dan nilai terendah 64 dengan rata-rata 73,77

Perbandingan hasil perhitungan nilai pre-test dan post test terlihat pada nilai tertinggi dan nilai terendah yang diperoleh anak dan terlihat pada rata-rata kelas eksperimen dan kelas kontrol pada post-test dimana pada post-test rata-rata menjadi lebih meningkat dari rata-rata pre-test setelah dilakukan treatment.

Pada pembelajaran dengan menggunakan Jari Tangan ini, guru berfungsi sebagai fasilitator, yang bertugas memberikan pengarahan dan contoh kepada anak. Keaktifan anak dalam membuat binatang jari dengan menggunakan jari tangan lebih ditekankan pada pembelajaran ini. Dengan adanya pembelajaran ini, kemampuan motorik halus anak dapat dikembangkan.

Dari uraian di atas, sangat jelas bahwa penggunaan Jari Tangan efektif dalam mengembangkan motorik halus anak. Hal ini terlihat dari perolehan nilai kemampuan motorik halus anak kelas eksperimen terdapat pengaruh daripada kelas kontrol yang menggunakan media konvensional (media daun). 


\section{PEMBAHASAN}

Dapat disimpulkan bahwa terdapat efektivitas penggunaan jari tangan dalam mengembangkan motorik halus anak di Taman Kanakkanak Bhayangkari 1 Padang. Dimana nilai anak di kelas eksperimen lebih tinggi dibandingkan kelas kontrol. Pada kelas Eksperimen (B5) Taman Kanak-kanak Bhayangkari 1 Padang, semua anak terlihat senang, antusias dan semangat untuk mencobanya yang mana media ini pada umumnya dianggap baru oleh anak di samping itu penggunaan jari tangan memiliki daya tarik tersendiri, karena menggunakan tangan sendiri, dan bisa membuat beberapa macam binatang seperti kupu-kupu, capung, burung, tanduk rusa, dan laba-laba sehingga dapat menambah minat, perhatian dan ketertarikan anak dalam belajar.

Sedangkan Kelas kontrol (B4) menggunakan media daun dalam mengembangkan motorik halus. Anak terlihat kurang antusias dan semangat dalam kegiatan berlangsung, dimana media ini sudah biasa bagi anak, karena menggunakan daun dan menggunakan kertas koran dan kurang menarik. Sehingga kurangnya minat, perhatian dan ketertarikan anak dalam belajar.

Penggunaan jari tangan didukung oleh beberapa teori diantaranya, Menurut Latif (2013:152) media adalah segala sesuatu yang dapat dijadikan bahan (software) dan alat (hardware) untuk bermain yang membuat AUD mampu memperoleh pengetahuan, keterampilan, dan menentukan sikap. selanjutnya Hidayati (2010: 62) mengemukakan mengenai perkembangan motorik halus adalah perkembangan gerakan yang dilakukan anak dengan sebagian anggota tubuh tertentu atau menggunakan otot-otot kecil, seperti menulis, menggunting, dan menyusun balok. Setiap perkembangan motorik halus dipengaruhi oleh kesempatan anak untuk belajar dan berlatih. Dengan begitu penggunaan jari tangan merupakan media yang mudah di dapat, karena menggunakan jari tangan sendiri. Selain itu dapat memberi gambaran, pengetahuan dalam mengembangkan motorik halus anak.

Jadi penggunaan jari tangan merupakan media yang berasal dari bagian anggota tubuh yaitu jari tangan yang bisa mengembangkan motorik halus. Dengan jari tangan dapat membuat beberapa macam binatang yang dijumpai anak, dimana dengan media ini anak bisa mengembangkan motorik halusnya dengan kegiatan menjiplak, mewarnai, menggunting, dan menempel.

\section{SIMPULAN}

Berdasarkan hasil analisis data penelitian yang telah dilakukan, maka dapat diambil kesimpulan bahwa terdapat efektivitas penggunaan jari tangan dalam mengembangkan motorik halus anak dibandingkan penggunaan media daun. Secara keseluruhan dengan 
menggunakan jari tangan terdapat efektivitas dalam mengembangkan motorik halus anak. Terdapat perbedaan yang signifikan antara hasil belajar kelompok eksperimen(B5) yang menggunakan jari tangan, dibandingkan kelompok kontrol (B4) yang menggunakan daun. Hal ini membuktikan bahwa dengan menggunakan jari tangan mempengaruhi pengembangan motorik halus aank, sehingga nilai rata-rata yang diperoleh dari kelas eksperimen tinggi $(83,33)$ dibandinggkan kelas kontrol 73,77. Bedasarkan uji hipotesis di dapatkan $t_{\text {hitung }}>t_{\text {tabel }}$ dimana $(4,138>2,03224)$ yang dibuktikan dengan taraf signifikan a 0,05 ini berarti terdapat efektivitas antara hasil pengembangan motorik halus anak yang menggunakan jari tangandengan kelas kontrol yang menggunakan daun. Dengan demikian penggunaan jari tangan terbukti dapat memberikan efektitivitas yang signifikan dalam mengembangkan motorik halus anak di Taman Kanak-Kanak Bhayangkari 1 Padang.

Berdasarkan hasil penelitian di atas, dapat dikemukakan beberapa saran sebagai berikut : penggunaan jari tangan diharapkan dapat dipergunakan sebagai salah satu alternatif pembelajaran dalam mengembangkan motorik halus anak bagi pendidik anak usia dini, sehingga dapat meningkatkan kualitas pembelajaran. Kepada peneliti yang ingin melanjutkan penelitian ini diharapkan dapat menerapkannya pada kelompok atau sampel yang lebih besar atau menerapkannya untuk mengengembangkan motorik halus anak.

\section{DAFTAR PUSTAKA}

Arikunto, Suharsimi. 2010. Prosedur Penelitian Suatu Pendekatan Praktik. Jakarta. Rineka Cipta

Desmita. 2009. Psikologi Perkembangan. Bandung: PT Remaja Rosdakarya

Fadlillah, Muhammad. 2012. Desain Pembelajaran PAUD. Jogjakarta: ArRuzz Media.

Hidayati, Zulaehah. 2010. Anak Saya Tidak Nakal, Kok. Yogyakarta: PT Bentang Pustaka.

Latif, Muchtar.,dkk. 2013. Orientasi Baru Pendidikan Anak Usia Dini. Jakarta: Kencana

Mulyani, Yani dan Juliska Gacinia. 2007. Kemampuan Fisik, Seni, dan Manajemen Diri. Jakarta: Gramedia

Sudono. 2006. Sumber Belajar dan Alat Permainan. Jakarta: PT Gramedia.

Sugiyono. 2012. Metode Penelitian Kuantitatif, Kualitatif, dan R\&D. Bandung: Alfabeta.

Syafril. 2010. Statistika. Padang: Sukabina Press.

Tim Redaksi KBBI. 2008. Kamus Besar Bahasa Indonesia (KBBI). Jakarta: Gramedia

Undang-undang RI Nomor 20 Tahun 2003 tentang Sistem Pendidikan Nasional. Jakarta: Sinar Grafika 